\title{
Wnt/ $\beta$-catenin signaling: Causes and treatment targets of drug resistance in colorectal cancer (Review)
}

\author{
GUI-XIAN ZHU ${ }^{1,2}$, DIAN GAO $^{3}$, ZHAO-ZHAO SHAO $^{1}$, LI CHEN $^{1}$, WEN-JIE DING ${ }^{1}$ and QIONG-FANG YU ${ }^{1}$ \\ ${ }^{1}$ Department of Gastroenterology and Hepatology, Second Affiliated Hospital of Nanchang University; \\ ${ }^{2}$ Second Clinical Medical College of Nanchang University; ${ }^{3}$ Department of Pathogen Biology and Immunology, \\ Medical College of Nanchang University, Nanchang, Jiangxi 330006, P.R. China
}

Received April 8, 2020; Accepted October 23, 2020

DOI: $10.3892 / \mathrm{mmr} .2020 .11744$

\begin{abstract}
Colorectal cancer (CRC) is the third most common malignant tumor in humans. Chemotherapy is used for the treatment of CRC. However, the effect of chemotherapy remains unsatisfactory due to drug resistance. Growing evidence has shown that the presence of highly metastatic tumor stem cells, regulation of non-coding RNAs and the tumor microenvironment contributes to drug resistance mechanisms in CRC. Wnt/ $\beta$-catenin signaling mediates the chemoresistance of CRC in these three aspects. Therefore, the present study analyzed the abundant evidence of the contribution of $\mathrm{Wnt} / \beta$-catenin signaling to the development of drug resistance in CRC and discussed its possible role in improving the chemosensitivity of CRC, which may provide guidelines for its clinical treatment.
\end{abstract}

\section{Contents}

1. Introduction

2. Method

3. Wnt $/ \beta$-catenin signaling pathway

4. Wnt/ $\beta$-catenin signaling in CRC drug resistance

5. Wnt inhibitors reduce the resistance of CRC

6. The role of $\mathrm{Wnt} / \mathrm{\beta}$-catenin signaling crosstalk in resistance

7. Conclusions

Correspondence to: Dr Qiong-Fang Yu, Department of Gastroenterology and Hepatology, Second Affiliated Hospital of Nanchang University, 1 Minde Road, Nanchang, Jiangxi 330006, P.R. China

E-mail: qiongfangyu@yeah.net

Key words: colorectal cancer, Wnt/ $\beta$-catenin signaling, drug resistance, tumor stem cells, non-coding RNAs, tumor microenvironment

\section{Introduction}

Globally, colorectal cancer (CRC) is the third most commonly diagnosed malignant tumor and is the second leading cause of cancer-associated mortality (1). Overall, the incidence rate and mortality rate of CRC are rising rapidly in several low-income and middle-income countries (2). Although the mortality rate of CRC tends to be stable or declining in developed countries, it is still higher than that in low-income and middle-income countries (2). By 2030, the global CRC burden is expected to increase by $60 \%$, reaching $>2.2$ million new cases and 1.1 million mortalities (3). The majority of newly-diagnosed CRC cases are classified as a sporadic form (4), and the occurrence and development of CRC is a long-term process. Conventional CRC begins with changes in the cell morphology of the colonic epithelium, which proliferates uncontrollably to form benign polyps. Gradually, it develops into a highly atypical hyperplastic advanced adenoma, which causes a loss of epithelial structure and function to form an invasive tumor $(5,6)$.

A number of factors contribute to the formation of CRC. Genetic susceptibility is a major driver of early CRC occurrence. A study has demonstrated that CRC contains $\leq 80$ mutations, of which $<15$ mutations are the driving force for tumorigenesis (7). The probability of developing CRC is also associated with personal features and habits, such as age, gender, race/ethnicity, chronic disease history, dietary factors, obesity, low physical activity, smoking and intestinal microflora $(4,8,9)$. Chemotherapy based on 5 -fluorouracil $(5-\mathrm{FU})$ has been the main treatment method for patients with CRC since the 1950s (10-12). More chemotherapeutic drugs, such as oxaliplatin (L-OHP), irinotecan and capecitabine, have been developed in recent years and the emergence of monoclonal antibodies, such as bevacizumab and cetuximab, have greatly advanced chemotherapy for CRC (13). However, even if the current response rate to various systemic chemotherapy regimens reaches $50 \%$, most patients develop resistance within 3-12 months $(14,15)$. Drug resistance refers to the gradual decline in the response to drugs during the treatment of various diseases (16). Resistance to chemotherapy drugs is a major limitation in the use of chemotherapy (17). The failure of chemotherapy due to cancer progression and resistance underlies the majority of cancer-associated deaths (18). Therefore, 
it is necessary to explore drug resistance mechanisms and reversal strategies of CRC chemotherapy.

Previous studies have demonstrated that tumor stem cells (CSCs), non-coding RNAs (ncRNAs) and disordered tumor microenvironment (TME) contribute to the resistance of CRC (19-22). Notably, Wnt/ $\beta$-catenin signaling has been reported to regulate the formation of CRC via these three aspects $(23,24)$. It is hypothesized that the dysregulation of the Wnt/ $\beta$-catenin signaling is related to chemotherapy resistance in CRC. At present, numerous studies have sustained this view (25-27), but there is no systematic summary to the best of our knowledge. Therefore, the present authors have systematically reviewed the reported studies on $\mathrm{Wnt} / \beta$-catenin signaling-mediated chemotherapy resistance of CRC, which may provide clinical reference for the future.

\section{Method}

Studies were retrieved from the Pubmed (https://pubmed.ncbi. nlm.nih.gov/) and Web of Science databases (https://www. webofknowledge.com) using 'Wnt', ' $\beta$-catenin', 'CRC', 'drug resistance' and 'multidrug resistance' (MDR) as key words. The retrieved literature ranged from 1980 to the present and the last search was performed on August 28, 2020. The present review focuses on the role of $\mathrm{Wnt} / \beta$-catenin signaling in $\mathrm{CRC}$ resistance and the inhibition of $\mathrm{Wnt} / \beta$-catenin signaling to study the regulation of $\mathrm{CRC}$ resistance.

\section{Wnt/ $\beta$-catenin signaling pathway}

The Wnt gene was first identified in mouse mammary tumors in 1982 and was originally named the int1 gene (28). Subsequent investigation showed that the int gene serves an important role in embryo growth and development in mice, and its function is similar to the Drosophila wingless gene (29). The int1 gene and wingless gene are collectively referred to as the Wnt gene (29). The Wnt signaling pathway is one of the key signaling pathways in the regulation of cell proliferation and it serves a significant role in the pathological process of malignant tumors (30-34). The Wnt gene is composed of various glycoproteins, is a member of the coiled family of transmembrane receptors and is the coreceptor for lipoprotein receptor-related protein (LRP) family and other downstream components (35). There are currently 19 Wnt ligands in mammals that function via autocrine and paracrine pathways $(36,37)$. These various Wnt ligands serve different roles in the development of organisms and the aberrant expression of Wnt ligand genes can lead to the occurrence and development of different types of tumors (Table I) (78). Wnt ligands are divided into two classes according to the different binding methods with downstream receptors. One group binds to the Frizzled (Fzd) and low-density lipoprotein-related receptor 5/6 (LRP/6) to activate canonical $\beta$-catenin-dependent pathways. The other group binds Fzd protein to activate the cyclic guanosine monophosphate protein and the noncanonical Wnt pathway (79). $\beta$-catenin is the central molecule in the canonical Wnt pathway that controls the switch of the Wnt signaling pathway. Therefore, it is also called $\mathrm{Wnt} / \beta$-catenin signaling (80). Wnt ligands do not bind to the receptor in normal mature cells, and $\mathrm{Wnt} / \beta$-catenin signaling is in an 'off' state (81). Adenomatous polyposis coli (APC) protein, framework protein Axin, glycogen synthase kinase $3 \beta$ (GSK $3 \beta$ ) and casein kinase 1 (CK1) form a complex that causes degradation of $\beta$-catenin (82). This complex degrades $\beta$-catenin, which is phosphorylated, modified by ubiquitin and ultimately degraded by the proteasome (83). Eventually, the concentration of $\beta$-catenin is decreased, nuclear translocation is suppressed, and downstream target genes, including c-Myc, cyclin D1, survivin and porous metalloproteinase, cannot be activated (83). When Wnt ligands bind to transmembrane Fzd receptors and LRP5/6, CK 1 and GSK $3 \beta$ are attracted to LRP5/6 and function as phosphorylases of LRP5/6, which prevents formation of the protein complexes that degrade $\beta$-catenin (84). Continuously increasing concentrations of free $\beta$-catenin enter the nucleus via the nuclear pore membrane and bind to transcription factor/lymphocyte-enhancing factor (TCF/LEF) (85). Binding promotes the transcription of downstream target genes that affect cell proliferation, apoptosis, stromal lysis and angiogenesis (85). Wnt ligands bind to the receptor, and Wnt $/ \beta$-catenin signaling is in an 'on' state (81). The details are shown in Fig. 1.

\section{Wnt/ $\beta$-catenin signaling in CRC drug resistance}

The resistance of human tumors to anticancer drugs is primarily due to the inherent chemical resistance of tumor cells, generally attributed to gene mutation, gene amplification or epigenetic changes, which affect absorption, metabolism or the export of drugs by a single cell (19). CRC cells exhibit varied resistance to different chemotherapy drugs, including 5-FU, L-OHP and irinotecan, depending on enhanced intracellular metabolism, upregulation or changes in intracellular targets, increased dihydropyrimidine dehydrogenase and thymidine synthase activities, upregulated levels of the diminished form glutathione or increased nucleotide excision repair $(86,87)$. Resistance to capecitabine is accomplished via methylation of the gene encoding thymidine phosphorylase and inactivation of capecitabine (88). For the checkpoint inhibitors, including ipilimumab, pembrolizumab and nivolumab, tumors primarily achieve resistance via tumor mutation and adaptation, decreased production or expression of neoantigens, overexpression of indoleamine 2,3-dioxygenase and decreased expression of phosphatase and tensin homolog (PTEN) (89). Ghadimi et al (90) reported that the Wnt transcription factor TCF7L2 is overexpressed in 5-FU-resistant primary rectal cancer. The stimulation of Wnt3a leads to the strong activation of Wnt/ $\beta$-catenin signaling in SW480, SW837 and LS1034 CRC cells (91). At the same time, the activity of TCF/LEF reporter gene is rapidly increased, which results in resistance to 5-FU (91). The inhibition of $\beta$-catenin can avoid the therapeutic resistance caused by enhanced TCF/LEF gene activity (91). Another study also demonstrated that the sensitivity of CRC cells to 5-FU can be adjusted through Wnt/ $\beta$-catenin signaling pathway (92). In addition, pharmacological or genetic inhibition of $\beta$-catenin can change the chemical sensitivity of SW480 and SW620 CRC cells to 5-FU and L-OHP by regulating the Wnt/ $\beta$-catenin-Jagged 2-p21 axis (93). Silencing of the 
Table I. Cancer types associated with the Wnt ligand genes.

\begin{tabular}{|c|c|c|c|c|}
\hline Author, year & Gene & Function & Type of cancer & (Refs.) \\
\hline $\begin{array}{l}\text { He et al, } 2004 \\
\text { Chen et al, 2004; Babaei et al, } 2019 \\
\text { Jia et al, 2017; Bodnar et al, } 2014\end{array}$ & Wnt1 & GOF & $\begin{array}{l}\text { Non-small-cell lung, prostate, CRC, } \\
\text { gastric and ovarian cancer }\end{array}$ & $(38-42)$ \\
\hline Huang et al, 2015; Katoh et al, 2001 & Wnt2 & GOF & Lung, prostate, gastric cancer and CRC & $(43,44)$ \\
\hline $\begin{array}{l}\text { Nakashima et al, 2012; Wang et al, } 2016 \\
\text { Nie et al, } 2019\end{array}$ & Wnt3 & GOF & Lung, CRC and gastric cancer & $(45-47)$ \\
\hline $\begin{array}{l}\text { Thiago et al, } 2010 \\
\text { Zimmerman et al, } 2013 \\
\text { Annavarapu et al, } 2013\end{array}$ & Wnt3a & LOF & $\begin{array}{l}\text { B cell precursor acute lymphoblastic } \\
\text { leukemia, multiple melanoma and } \\
\text { alveolar rhabdomyosarcoma }\end{array}$ & $(48-50)$ \\
\hline $\begin{array}{l}\text { Fox et al, 2013; Wang et al, } 2014 \\
\text { Akaboshi et al, } 2009\end{array}$ & Wnt3a & GOF & $\begin{array}{l}\text { Malignant mesothelioma, } \\
\text { breast and pancreatic cancer }\end{array}$ & $(51-53)$ \\
\hline Zhao et al, 2019 & Wnt4 & GOF & Cervical cancer & $(54)$ \\
\hline $\begin{array}{l}\text { McDonald et al, 2009; Li et al, } 2010 \\
\text { Ying et al, } 2008 \\
\text { Kremenevskaja et al, } 2005 \\
\text { Thiele et al, 2016; Kurayoshi et al, } 2006\end{array}$ & Wnt5a & LOF & $\begin{array}{l}\text { Prostate and breast cancer, } \\
\text { neuroblastoma, leukemia, squamous } \\
\text { cell carcinoma of the esophagus, } \\
\text { CRC and thyroid cancer }\end{array}$ & $(55-59)$ \\
\hline $\begin{array}{l}\text { Kurayoshi et al, } 2006 \\
\text { Kurayoshi et al, 2006; Huang et al, } 2005 \\
\text { Bo et al, } 2013\end{array}$ & Wnt5a & GOF & $\begin{array}{l}\text { Prostate, gastric, pancreatic, ovarian and } \\
\text { non-small-cell lung cancer }\end{array}$ & $(59-62)$ \\
\hline Navarrete-Meneses et al, 2017 & Wnt5b & GOF & Acute lymphoblastic leukemia & $(63)$ \\
\hline Stewart et al, 2014 & & & & \\
\hline Kirikoshi et al, 2002 & Wnt7a & LOF & $\begin{array}{l}\text { Non-small cell lung cancer, CRC, } \\
\text { pancreatic and gastric cancer }\end{array}$ & $(64,65)$ \\
\hline $\begin{array}{l}\text { Huang et al, 2015; Kirikoshi et al, } 2002 \\
\text { Vesel et al, } 2017\end{array}$ & Wnt7b & GOF & $\begin{array}{l}\text { Breast cancer, adenocarcinoma and } \\
\text { embryonal tumor }\end{array}$ & $(43,65,66)$ \\
\hline $\begin{array}{l}\text { Li et al, 2019; Li et al, 2017; Hsu et al, } 2012 \\
\text { Kirikoshi et al, 2001; Dong et al, } 2017\end{array}$ & Wnt10a & GOF & $\begin{array}{l}\text { CRC, ovarian cancer, renal cell carcinoma, } \\
\text { esophageal and gastric cancer and papillary } \\
\text { thyroid carcinoma }\end{array}$ & $(67-71)$ \\
\hline $\begin{array}{l}\text { Wend et al, 2013; Chen et al, } 2013 \\
\text { Saitoh et al, } 2001\end{array}$ & Wnt10b & GOF & $\begin{array}{l}\text { Triple-negative breast and endometrial } \\
\text { cancer and gastric carcinogenesis }\end{array}$ & $(72-74)$ \\
\hline Bartis et al, 2013; Tian et al, 2018 & Wnt11 & GOF & Lung cancer and CRC & $(75,76)$ \\
\hline Toyama et al, 2010 & Wnt11 & $\mathrm{LOF}$ & Hepatocellular carcinoma & (77) \\
\hline
\end{tabular}

$\mathrm{T}$ cell factor 4 (Tcf4) gene, which is a downstream effector of Wnt/ $\beta$-catenin signaling, sensitizes SW1874, SW1396, SW480 and SW-Sc CRC to L-OHP. This sensitization effect may be due to different mechanisms, including the Tcf4 motif in the ATP-binding cassette subfamily B member 1 (ABCB1) promoter, defects in the nucleotide excision repair or double strand break repair system after Tcf4-silencing (87). Wnt inhibitors also improve chemosensitivity $(94,95)$. Among these inhibitors, 4-acetylantroquinol $\mathrm{B}$, which is isolated from the mycelia of Ganoderma camphora, negatively regulates the stem cell maintenance signaling transduction pathway LGR5/Wnt/ $\beta$-catenin and is most effective in reducing stem-related chemical resistance (96). The present study mainly reviewed the molecular mechanisms of
Wnt/ $\beta$-catenin signaling through CSCs, ncRNAs and TME that mediate the chemotherapy resistance of CRC.

Wnt/ $\beta$-catenin signaling and CSCs. CSCs are cells that promote the development of tumors, and have the ability to self-renew and have multiple differentiation potentials $(97,98)$. CSCs have four known characteristics, including self-renewal, differentiation, tumorigenic and specific surface markers. These cells are responsible for tumor occurrence, development, metastasis, recurrence and drug resistance $(20,99)$. CSCs are naturally chemoresistant. CSCs are functionally protected in the tissue stem cell niche during chemotherapy (100). The CSCs niche is mainly composed of fibroblasts and endothelial, mesenchymal and immune cells $(101,102)$. These adjacent cells 
A

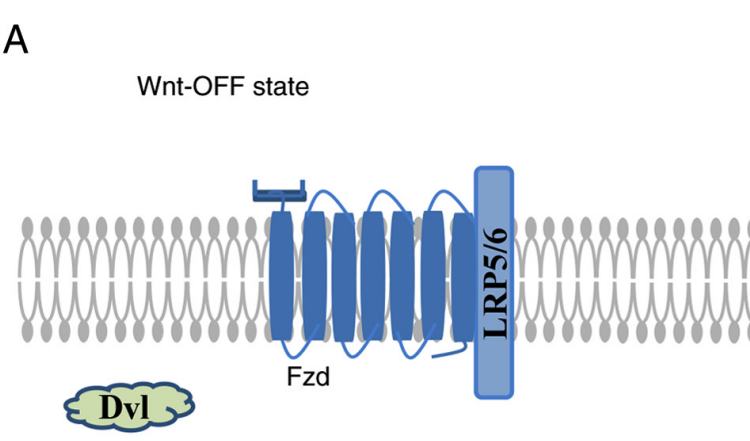

$B$
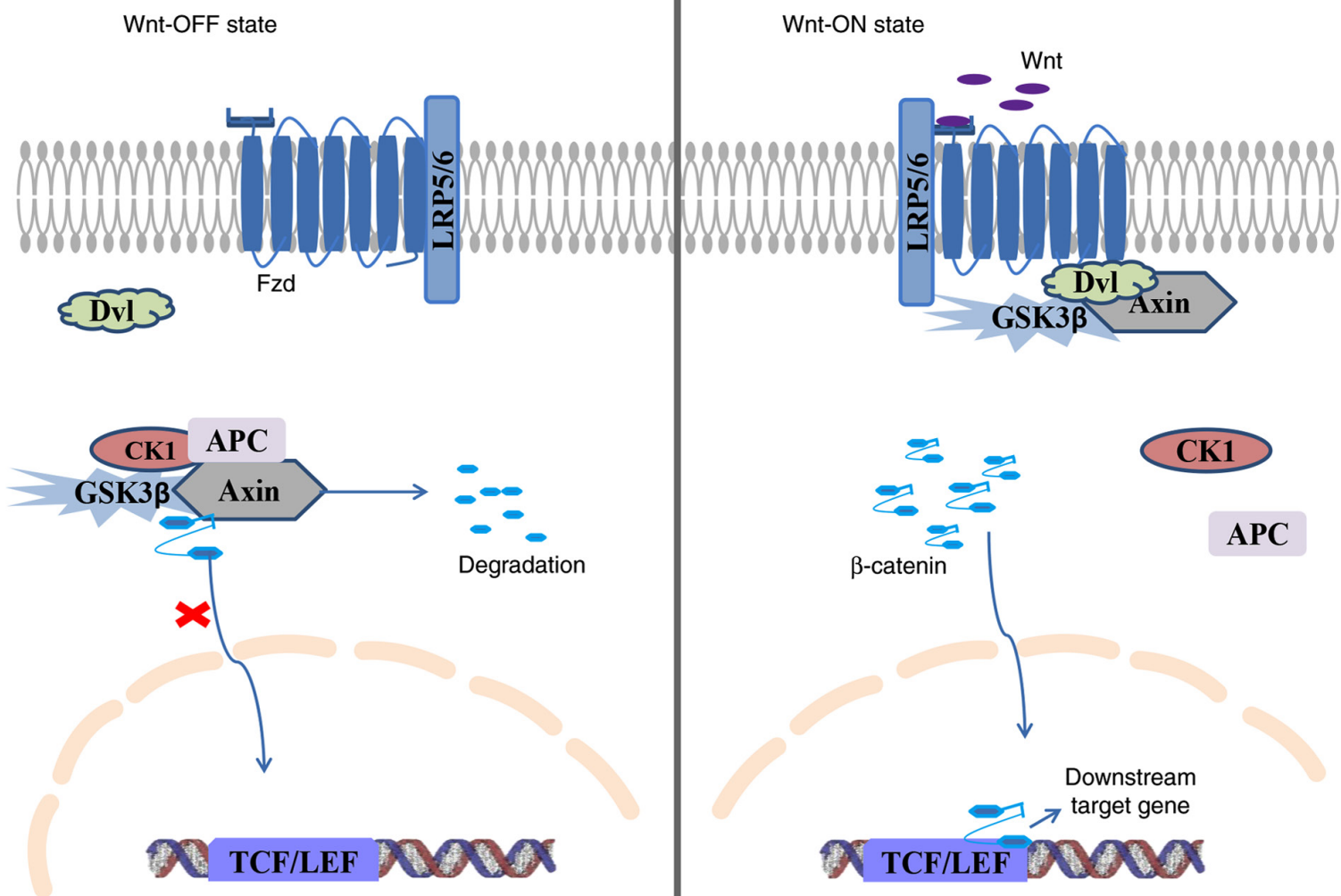

Figure 1. Schematic representation of the Wnt/ $\beta$-catenin signaling pathway. (A) Wnt-off state. Cytoplasmic $\beta$-catenin is phosphorylated by a destructive complex composed of Axin, APC, GSK3 $\beta$ and CK1, then it is ubiquitinated and targeted for proteasome degradation. (B) Wnt-on state. Binding of Wnt ligands and its receptor Dvl determines the destruction of the $\beta$-catenin destruction complex, which induces the stability of $\beta$-catenin. $\beta$-catenin is transferred to the nucleus as a cofactor of TCF/LEF to activate Wnt target gene. Dvl, Dishevelled; APC, $\alpha$ denomatous polyposis coli; GSK3 $\beta$, glycogen synthase kinase $3 \beta$; CK1, casein kinase 1; Dvl, Fzd/LRP5/6/Dishevelled; TCF/LEF, transcription factor/lymphocyte-enhancing factor binding factor; Fzd, Frizzled; LRP5/6, low-density lipoprotein-related receptor $5 / 6$.

promote the molecular signaling pathways required for the maintenance and survival of CSCs and trigger the endogenous drug resistance of CSCs (103). In addition, the extracellular matrix of niches can protect CSCs from the invasion of therapeutic drugs (100).

Wnt/ $\beta$-catenin signaling is a necessary pathway for the initial activation, self-renewal and cloning ability of CSCs (104). Fevr et al (105) reported that tissue-specific and inducible $\beta$-catenin gene ablation blocks Wnt/ $\beta$-catenin signaling and reduces the proliferation ability of CSCs. Wnt $/ \beta$-catenin signaling regulates the expression of surface markers of CSCs $(106,107)$. Leucine-rich repeat-containing G-protein-coupled receptor 5 (LGR5) is a target gene of the Wnt pathway and a marker of CSCs (107). Activation of Wnt/ $\beta$-catenin signaling increases the level of the CSC cell surface marker LGR5 in the CRC cell lines HCT116, SW480 and DLD1 and enriches gene signatures associated with stemness and cancer relapse in CSCs (108). LGR5-positive CSCs are chemotherapy-resistant (109). The rapid proliferation of CSCs may transform LGR5-negative cells into LGR5-positive cells, which makes the cells enter a static state to escape the toxicity of drugs (110). However, CSCs of the CRC cell lines LoVo, HT29 and HCT116 also obtain drug resistance via the upregulation of drug-resistant drug pumps mediated by LGR5 (107). As CSCs and normal stem cells have very similar characteristics, most of these cells are in the $G_{0}$ phase of the cell cycle and express specific ATP-binding cassette proteins (ABC transporter) (111). The ABC transporter is a drug pump that mediates the outflow or uptake of a specific substrate. This mechanism takes place at cell membranes (including plasma membrane, endoplasmic reticulum, Golgi body, peroxisome and mitochondria) (112). ABC transporters expel numerous types of drugs from cancer cells and induce chemical resistance in numerous solid tumors $(113,114)$. ABCB1 was the first cloned human $A B C$ transporter (115). A study has shown that $A B C$ inhibitors can inhibit $A B C$ transporters with high potency and specificity and do not adversely affect the pharmacokinetics of therapeutic drugs that can kill cancer cells (116). NSC239225, as one of the ABC transporter inhibitors, can inhibit ABCB1 to increase the sensitivity of SW480TR CRC cells to some drugs, such as paclitaxel (PTX), doxorubicin and mitoxantrone. Its inhibitory effect is mainly achieved through stimulating ATP hydrolysis and directly binding to the iodoarylazidoprazosin (IAAP)-specific substrate binding site (117). Parguerenes I and II, which also act as $\mathrm{ABC}$ transporter inhibitors, can repress $\mathrm{ABCB} 1$ by modifying the extracellular substrate binding site of $\mathrm{ABCB}$, thereby reducing the resistance of SW620 and SW620 Ad300 CRC cells to PTX, Doxorubicin and vincristine (118). Studies have shown that $\mathrm{Wnt} / \beta$-catenin signaling is closely 
related to the ABC transporter of CSCs $(25,119)$. Inhibition of $\mathrm{Wnt} / \beta$-catenin signaling downregulates the expression of mRNA related to the ABC transporter, which makes SW480 CRC cells more sensitive to PTX and irinotecan (25). The ABCB1 level of SW620/AD CRC cells is also positively correlated with $\mathrm{Wnt} / \beta$-catenin signaling transduction activity (120). Notably, Kugimiya et al (121) demonstrated that the downstream target gene of the Wnt/ $\beta$-catenin signaling, c-Myc, makes COLO-320 CRC cells resistant to the chemical 5-FU by regulating the expression of $\mathrm{ABCB} 5$. This effect is primarily achieved by c-Myc-mediated regulation of the $\mathrm{ABC}$ transporter gene expression via binding to the upstream promoter (121). Wang et al (122) demonstrated that the transient receptor potential channel short transient receptor potential channel 5 (TRPC5)-induces an increase in $\left[\mathrm{Ca}^{2+}\right]$, promoting the transport of $\beta$-catenin to the nucleus, which serves an important role in ABCB1-induced resistance to 5-FU in CRC cells. Inhibition of TRPC5 using TRPC5-specific siRNA further inhibits the Wnt/ $\beta$-catenin signaling pathway, reduces the induction of ABCB1 and reverses the resistance of HCT- 8 and LoVo CRC cells to 5-FU (122).

Increased glycolysis is also an important cause of CSC drug resistance. The stem cell niche is an anoxic functional chamber that induces CSCs to reprogram for glycolysis (123). This effect promotes the expression of genes involved in apoptosis resistance, which enables the cells to survive in a hostile environment and avoid the influence of chemotherapy (123). Abnormal activation of $\mathrm{Wnt} / \beta$-catenin signaling transduction is observed in a number of types of human cancer, which promotes glycolysis via the upregulation of solute carrier family 2 , facilitated glucose transporter member 1 expression through its target gene c-Myc (124). The role of Wnt/ $\beta$-catenin signaling transduction in promoting glycolysis is related to drug resistance (125)

Wnt/ $\beta$-catenin signaling and $n c R N A s$. Unlike mRNA, ncRNAs lack the potential to encode proteins or peptides (126). ncRNAs are divided into microRNAs (miRNAs/miR) (20-24 nt) (127), long non-coding RNAs (lncRNA) (>200 nt) (128), extracellular RNAs (129), circular RNAs (crcRNA) (130) (100-10,000 nt) and intronic RNAs (131). Previous studies have demonstrated that IncRNAs and miRNA affect the chemotherapy sensitivity of CRC cells via regulation of the Wnt/ $\beta$-catenin signaling pathway (Table II) $(26,131,132)$. miRNAs regulate $\mathrm{Wnt} / \beta$-catenin signaling by targeting Wnt ligands (133). Wnt10b is the downstream target of miR-148a, and miR-148a-overexpression inhibits Wnt10b expression and Wnt/ $\beta$-catenin signaling activity, enhancing cisplatin resistance in SW480 CRC cells (26). Another study demonstrated that miR-103/107 prevents the ormation of the $\beta$-catenin complex by repressing Axis inhibition protein 2, which prolongs the duration of Wnt $/ \beta$-catenin signaling and leads to the continuous induction of Wnt-responsive genes (131). Persistent effects of Wnt/ $\beta$-catenin signaling stimulates multiple stem-like features in HCT116 and HT29 CRC cells, including chemical resistance (131). GSK3 $\beta$ is also an important component of the $\beta$-catenin complex. Inhibition of miR-224 upregulates GSK $3 \beta$ expression in $\mathrm{Wnt} / \beta$-catenin signaling (134). Therefore, Wnt/ $\beta$-catenin signaling activity and survivin (an apoptosis inhibitory gene) expression are inhibited, which reduces the adriamycin resistance of CRC SW480 cells $(134,135)$. miR-506 also reverses the downstream target genes of MDR protein 1 (MDR1)/permeability-glycoprotein (P-gp)-mediated L-OHP resistance via inhibition of $\mathrm{Wnt} / \beta$-catenin signaling (132). $\mathrm{Wnt} / \beta$-catenin signaling also acts on some miRNAs to regulate the resistance to CRC (136-138). The P53 gene is a well-known tumor suppressor gene (136). Extensive research has reported that mutant p53 not only serves a key role in the transformation process of CRC, but also contributes to the invasiveness of CRC $(137,138)$. Since the discovery of the P53 gene, the regulation of the p53 pathway has aroused interest (139). There is a negative regulatory relationship between wild-type P53 and MDR1, which enhances tumor cell sensitivity to 5-FU (140). Patients with mutant p53 genes are generally resistant to CRC therapies and have a poor prognosis (141). Kwak et al (142) reported that the ectopic expression of miR-552 enhances the resistance to drug-induced apoptosis and that miR-522 directly targets p53. Further genetic and pharmacological experiments showed that the $\mathrm{Wnt} / \beta$-catenin signaling pathway and its main downstream target, c-Myc, increase the level of miR-552 (142). Therefore, Wnt regulates tumor suppressor genes via miRNAs, which leads to drug resistance. Wnt/ $\beta$-catenin signaling also transactivates miR-372/373 (143). Overexpression of miR-372/373 enhances the stemness of CRC cells by enriching CD26/CD24, which promotes self-renewal, chemotherapy resistance and the invasion of CRC cells (144).

IncRNAs also affect the chemosensitivity of CRC by regulating the Wnt/ $\beta$-catenin signaling (145-157). Han et al (145) used reverse transcription-quantitative PCR and functional testing of CRC tissues and cell lines and identified that lncRNA CRNDE activates the downstream targets $\beta$-catenin and TCF4 via binding to miR-181a-5p, which causes resistance to 5-FU and L-OHP. Xiao et al (146) demonstrated that IncRNA HOTAIR knockout and mir-203a-3p overexpression inhibited the Wnt/ $\beta$-catenin signaling pathway, thereby inhibiting cell proliferation and reducing chemoresistance. Another study confirmed that lncRNA H19 increases proliferation via activation of the Wnt/ $\beta$-catenin signaling, which promotes the resistance of HT-29 CRC to methotrexate (147). CRC-related IncRNA CCAL is another key regulator of CRC progression. Clinical data has demonstrated that patients with CRC with high CCAL expression have shorter overall survival rates, and promotes the resistance of CRC cells to L-OHP (148). A subsequent study showed that the CCAL promoter region possesses reduced methylation and increased acetylation in patients with CRC, which promotes its expression. Upregulated CCAL activates $W n t / \beta$-catenin signaling via inhibition of activating enhancer-binding protein $2 \alpha$, which upregulates MDR1P-gp and induces MDR (149).

Wnt/ $\beta$-catenin signaling and TME. Previous studies of chemical resistance primarily focused on the tumor cells themselves, but TME has also received attention $(150,151)$. Various cytokines secreted in the tumor microenvironment, including those from cancer-associated fibroblasts (CAFs), immune cells, inflammatory factors and chemokines, may interact with $\mathrm{Wnt} / \beta$-catenin signaling to cause a heterogeneous distribution of $\beta$-catenin in cells (152-154). Clear colocalization between CAFs and tumor cells expressing nuclear $\beta$-catenin is observed in primary CRC samples (27). These findings indicate a close 
Table II. ncRNAs regulate Wnt/ $\beta$-catenin signaling in colorectal cancer drug resistance.

\begin{tabular}{|c|c|c|c|c|c|c|}
\hline Author, year & ncRNAs & Dysregulation & Target & Mechanism & $\begin{array}{c}\text { Function on } \\
\text { drug resistance }\end{array}$ & (Refs.) \\
\hline Shi et al, 2019 & $\operatorname{miR}-148 \mathrm{a}$ & Upregulated & Wnt10b & $\begin{array}{l}\text { Inhibiting the } \\
\text { Wnt/ } \beta \text {-catenin signaling }\end{array}$ & $\begin{array}{l}\text { Increasing } \\
\text { cisplatin-sensitivity }\end{array}$ & (26) \\
\hline Chen et al, 2019 & $\operatorname{miR}-103 / 107$ & Upregulated & Axin2 & $\begin{array}{l}\text { Prolonging the duration } \\
\text { of } \mathrm{Wnt} / \beta \text {-catenin signaling }\end{array}$ & $\begin{array}{l}\text { Increasing } \\
\text { drug resistance }\end{array}$ & $(131)$ \\
\hline Liang et al, 2017 & $\operatorname{miR}-224$ & Upregulated & GSK $-3 \beta$ & $\begin{array}{l}\text { Inhibiting Wnt/ } \\
\beta \text {-catenin signaling } \\
\text { activity and survivin } \\
\text { expression }\end{array}$ & Decreasing MDR & $(134)$ \\
\hline Zhou et al, 2017 & miR-506 & Upregulated & $\beta$-catenin & $\begin{array}{l}\text { Inhibiting the } \\
\text { expression of MDR } 1 / \\
\text { P-gp of Wnt/ } \beta \text {-catenin } \\
\text { signaling }\end{array}$ & $\begin{array}{l}\text { Enhancing } \\
\text { L-OHP sensitivity }\end{array}$ & $(132)$ \\
\hline Kwak et al, 2018 & $\operatorname{miR}-552$ & Upregulated & P53 gene & $\begin{array}{l}\text { Activated by Wnt/c-Myc } \\
\text { axis to inhibit p53 }\end{array}$ & $\begin{array}{l}\text { Increasing drug } \\
\text { resistance }\end{array}$ & $(142)$ \\
\hline Wang et al, 2018 & $\operatorname{miR}-372 / 373$ & Upregulated & l & $\begin{array}{l}\text { Activated by Wnt/ } \\
\beta \text {-catenin signaling to } \\
\text { enrich CD26/CD24 }\end{array}$ & $\begin{array}{l}\text { Increasing drug } \\
\text { resistance }\end{array}$ & $(144)$ \\
\hline Han et al, 2017 & CRNDE & Upregulated & $\operatorname{miR}-181 a-5 p$ & $\begin{array}{l}\text { Activating } \\
\beta \text {-catenin and TCF4 }\end{array}$ & $\begin{array}{l}\text { Causing resistance to } \\
5-\mathrm{FU} \text { and L-OHP }\end{array}$ & $(145)$ \\
\hline Xiao et al, 2018 & HOTAIR & Upregulated & $\operatorname{miR}-203 a-3 p$ & $\begin{array}{l}\text { Activating Wnt/ } \\
\beta \text {-catenin signaling }\end{array}$ & Promoting cell resistance & $(146)$ \\
\hline Wu et al, 2017 & H19 & Upregulated & l & $\begin{array}{l}\text { Activating Wnt/ } \\
\beta \text {-catenin signaling to } \\
\text { activate proliferation }\end{array}$ & $\begin{array}{l}\text { Promoting resistance } \\
\text { to the MTX }\end{array}$ & $(147)$ \\
\hline Ma et al, 2016 & CCAL & Upregulated & AP- $2 \alpha$ & $\begin{array}{l}\text { Activating Wnt/ } \\
\beta \text {-catenin signaling to } \\
\text { upregulate MDR1P-gp } \\
\text { expression }\end{array}$ & Inducing MDR & $(149)$ \\
\hline
\end{tabular}

\footnotetext{
/ indicates that detailed information was not provided in the reference. miR, microRNA; ncRNAs, non-coding RNAs; Axin2, Axis inhibition protein2; GSK3 $\beta$, glycogen synthetase 3 $\beta$; MDR, multidrug resistance; 5-FU, 5-fluorouracil; MTX, methotrexate; CRNDE, long non-coding RNA CRNDE; TCF4, T cell factor4; H19, long non-coding RNA H19; HOTAIR, long non-coding RNA HOTAIR; CCAL, long non-coding RNA CCAL; AP- $2 \alpha$, activating enhancer-binding protein $2 \alpha$; MDR1P-gp, MDR1P-glycoprotein.
}

relationship between drug resistance and the tumor environment, especially CAFs (27). A study has demonstrated that exosomes are ideal carriers for the delivery of insoluble hydrophobic Wnt proteins (155). CAF-derived exosomes contribute to the secretion of Wnt ligands, promote the phenotypic recovery of differentiated CRC cells and the function of CSCs characteristics by carrying Wnt ligands. These ligands activate Wnt/ $\beta$-catenin signaling to regulate Wnt activity (27). All of these actions contribute to drug resistance (Fig. 2). $\mathrm{Hu}$ et al (156) treated human SW480, SW620 and LoVo CRC cells with CAF-conditioned medium (CAFs-CM). The results showed that CAF secretes exosomes into CRC cells, which leads to a significant increase in miR-92a-3p levels in CRC cells. The increased expression of miR-92a-3p activates the $\mathrm{Wnt} / \beta$-catenin pathway and inhibits mitochondrial apoptosis via direct inhibition of the tumor suppressor gene F-box/WD repeat-containing protein 7 and apoptosis regulator 1 , which promotes the resistance of CRC cells to 5-FU/L-OHP (157). Similarly, periodin secreted by fibroblasts also activates Wnt/ $\beta$-catenin signaling, which promotes differentiated CRC cells to restore CSCs characteristics and functions (158). DNA damage caused by chemotherapy promotes CAFs to produce numerous soluble factors, including Wnt16B and stable free radical polymerization 2 (SFRP2) (159). Wnt16B promotes tumor growth via activation of the canonical pathway in cancer cells, which reduces treatment sensitivity (159). SFRP2 acts as a synergistic effector that further enhances the drug resistance of Wnt16B/ $\beta$-catenin (160). SFRP2 also participates in the non-canonical pathway, including angiogenesis, via activation of calcineurin/nuclear factor of activated T cells, cytoplasmic 3 


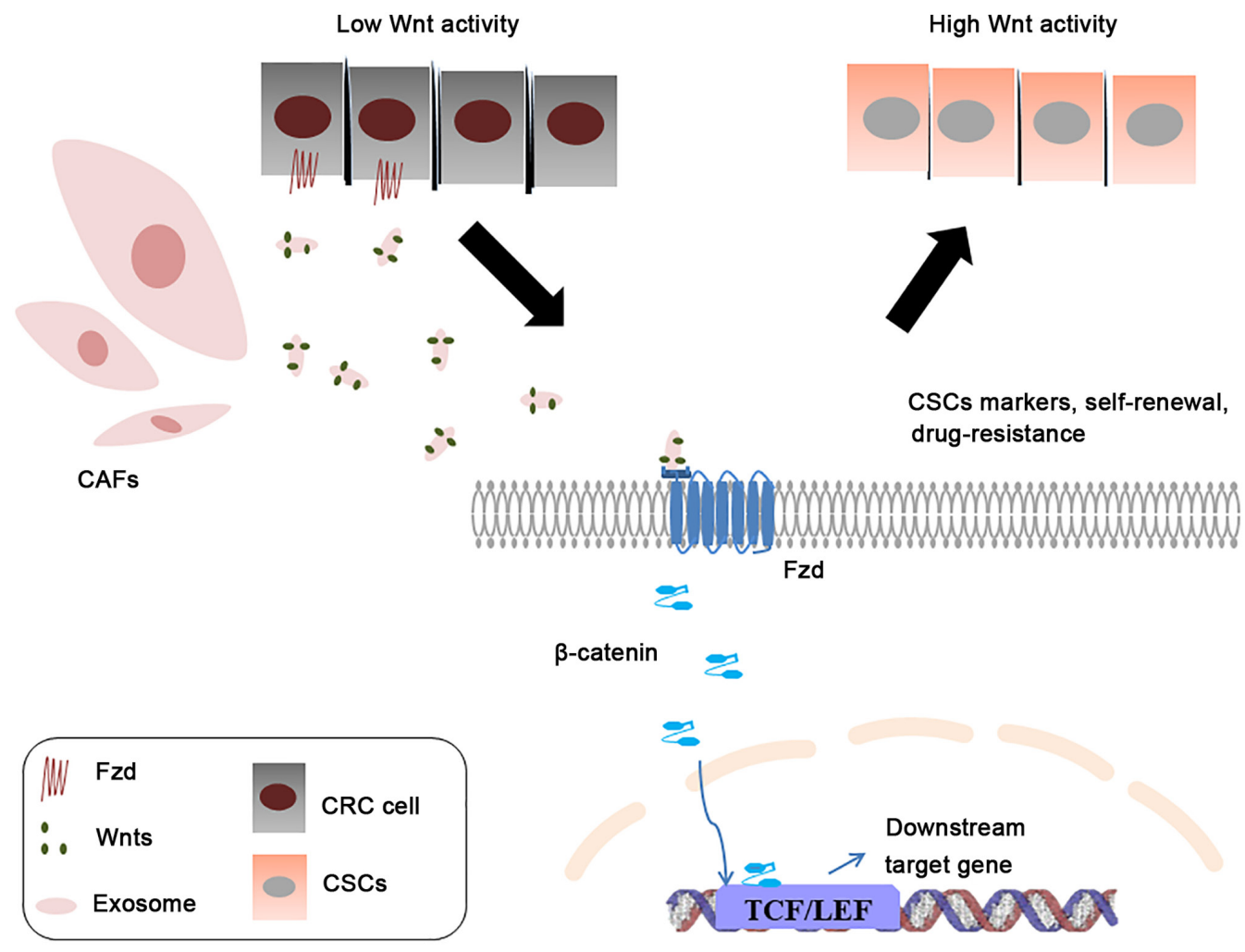

Figure 2. CAFs stimulate CRC cells to restore CSCs characteristics. CAFs are similar to CRC cells. CAFs secrete exosomes that carry Wnts, which stimulate differentiated CRC cells to restore their CSCs properties, including the expression of CSCs markers and increased Wnt activity. This process contributes to the development of drug resistance. CAFs, cancer-associated fibroblasts; CSCs, tumor stem cells; CRC, colorectal cancer; Fzd, Frizzled; TCF/LEF, transcription factor/lymphocyte-enhancing factor-binding factor; SFRP2, stable free radical polymerization 2.

signaling in endothelial cells, which indirectly promotes tumor development (Fig. 3) (160). Cancer-associated CAFs in CRC cells upregulate Wnt signaling-related genes, T-lymphoma infiltration and metastasis-inducing protein 1, and ultimately enhance the resistance of CRC by increasing the expression of tumor stem cells (161). BCL-9 serves a key role in promoting chemoresistance via the Wnt signaling pathway (162). Hypoxia in the TME leads to the upregulation of the key Wnt coactivator BCL-9 in a hypoxia-inducible factor- $1 \alpha / 2 \alpha$-related manner (163). There is crosstalk between Wnt signaling and the hypoxia signaling pathway. This crosstalk synergistically acts on the development of CRC resistance (163).

Immunotherapy targeting TME is an important treatment for CRC (151). Programmed death-1 (PD-1) is a coinhibitory molecule on T cells. The interaction of PD-1 and its ligand PD-L1 affects the use of metabolic substrates and results in $\mathrm{T}$ cell failure and immune escape of tumor cells (164). Therefore, monoclonal antibodies that inhibit immune checkpoint receptors, including PD-1, are approved for the treatment of CRC (165). However, a significant proportion of patients remain clinically unresponsive to this treatment (166-168). The occurrence of this low sensitivity may be related to the reduction of pre-existing $\mathrm{CD} 8^{+} \mathrm{T}$ cells that are negatively regulated by $\mathrm{PD}-1 / \mathrm{PD}-\mathrm{L} 1-\mathrm{mediated}$ adaptive immune resistance $(169,170)$. Notably, Wnt/ $\beta$-catenin signaling results from the exclusion of $\mathrm{CD}^{+} \mathrm{T}$ cells, which results in resistance to PD-1 inhibitors (171). Abnormal Wnt/ $\beta$-catenin signaling activation in CRC significantly increases the infiltration of regulatory $\mathrm{T}$ cells (Tregs), effective inhibitors of $\mathrm{CD} 8^{+} \mathrm{T}$ cells.
Tregs promote resistance by negating the function of cytotoxic $\mathrm{CD}^{+} \mathrm{T}$ cells (172). In addition to Tregs, dendritic cells (DCs) represent another important component of the immune cells that regulate tumor cell resistance (94). Tumor-resident CD103 ${ }^{+}$ DCs are necessary for the recruitment of $\mathrm{CD} 8^{+} \mathrm{T}$ cells (171). Blockade of $\mathrm{Wnt} / \beta$-catenin signaling in CRC cells increases DC infiltration, which leads to a significant increase in active $\mathrm{CD}^{+} \mathrm{T}$ cells in CRC models and the consequent sensitizing of cancer cells to PD-1 inhibitors (172). Overall, these studies suggest that $\mathrm{Wnt} / \beta$-catenin signaling mediates $\mathrm{CRC}$ resistance to immunotherapy via the regulation of immune cells in TME and provides a promising strategy for cancer therapy via the inhibition of Wnt/ $\beta$-catenin signaling.

\section{Wnt inhibitors reduce the resistance of CRC}

A number of Wnt inhibitors avoid resistance to drug recognition and work in conjunction with current clinical front-line drugs for CRC. Several studies are focused on Wnt inhibitors in 5-FU resistance $(56,94,173)$. Coumarin Esculetin (EST) reduces the release of E-cadherin, vimentin, $\beta$-catenin, $\mathrm{c}-\mathrm{Myc}$, cyclin D1, Wnt3a and VEGF, which inhibit Wnt/ $\beta$-catenin signaling (174). In vitro and in vivo experiments have shown that EST combined with 5-FU enhances the sensitivity of HT-29, SW480, HCT-116 and Caco-2 CRC cells to 5-FU (174). Similarly, the use of the multikinase inhibitor regorafenib increases miR-34a levels and reverses 5-FU resistance and the cancer-initiating cell phenotype by degrading Wnt/ $\beta$-catenin in HCT-116R and DLD-1R CRC cells (175). In vitro experimental 


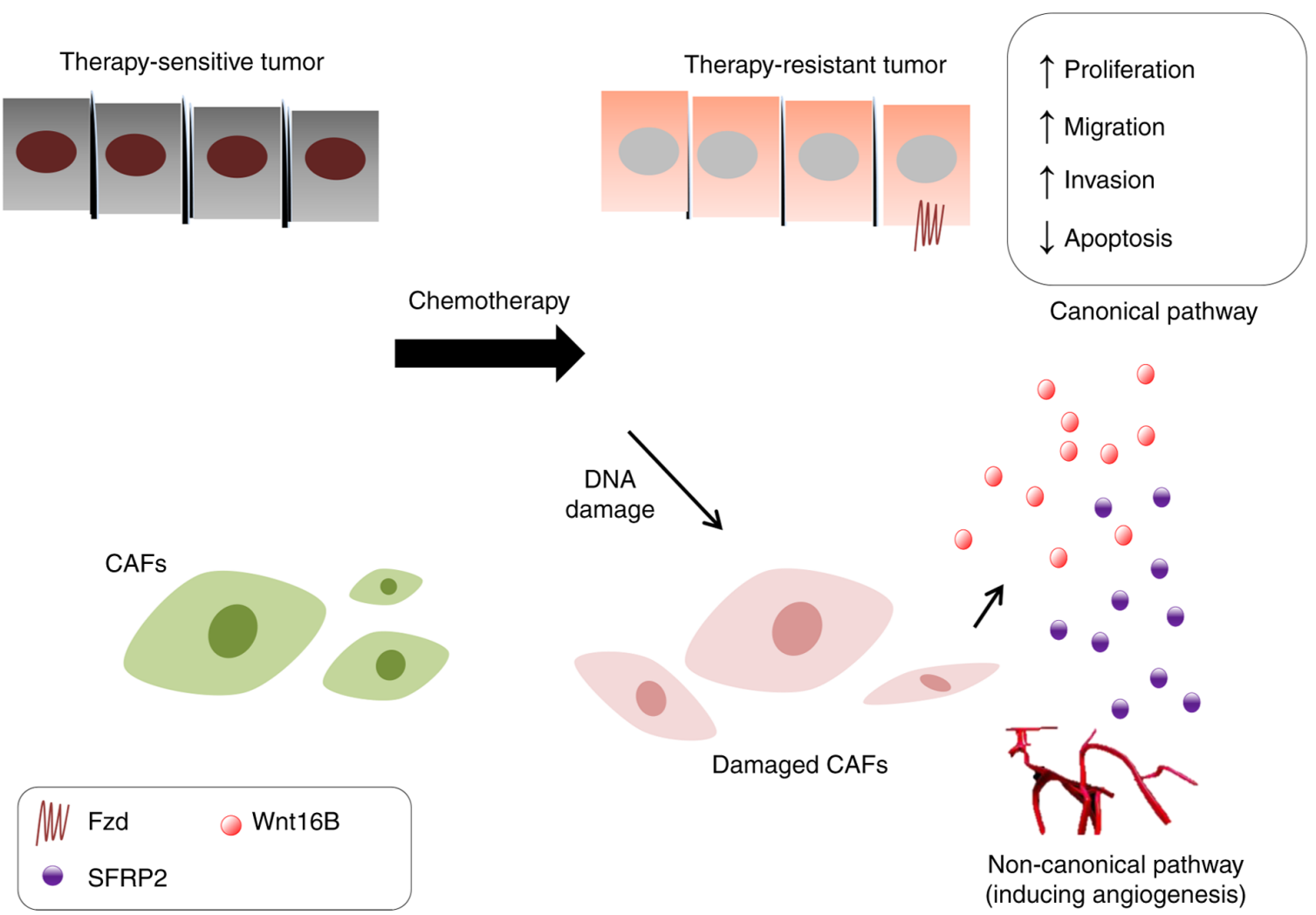

Figure 3. CAFs act on the Wnt pathway to promote tumor development. DNA damage caused by chemotherapy may result in CAF production of Wnt16B and SFRP2. Wnt16B promotes tumor growth via activation of the canonical pathway in cancer cells, which reduces treatment sensitivity. SFRP2 acts as a synergistic effector. SFRP2 may also participate in non-canonical pathways, such as angiogenesis, which indirectly promotes tumor development. CAFs, cancer-associated fibroblasts; Fzd, Frizzled; SFRP2, stable free radical polymerization 2.

results showed that the inhibition of the Wnt/ $\beta$-catenin signaling cascade using the tankyrase inhibitor XAV939 overcomes the resistance of CRC cells carrying short APCs to 5-FU (176). The upregulation of guanylate-binding protein-1 enhances the killing effect of PTX in PTX-sensitive CRC cells and PTX-resistant CRC cells via inhibition of $\mathrm{Wnt} / \beta$-catenin signaling in the CRC cell lines DLD-1, HT29, DiFi, T84 and HCT116 (177). Wu et al (178) reported that the synergistic use of cinnamaldehyde and L-OHP inhibits hypoxia-activated Wnt/ $\beta$-catenin signaling, reverses EMT, actives CSC and diminishes the occurrence of L-OHP resistance. Patients with CRC with KRAS mutations are not sensitive to cetuximab and panitumumab (179). The potent and selective Wnt/ $\beta$-catenin inhibitor KYA1797K activates GSK3 $\beta$ and degrades small $\beta$-catenin and Ras molecules to increase the sensitivity of tumors bearing KRAS mutations to cetuximab and panitumumab (180). These results indicate that Wnt signaling leads to chemoresistance in CRC. These studies highlight that the use of Wnt inhibitors affects the chemical sensitivity of cells to other drugs, which provides new approaches for the clinical treatment of CRC.

\section{The role of Wnt/ $\beta$-catenin signaling crosstalk in resistance}

Activation of the checkpoint kinase 1 (CHK1) pathway enhances the drug sensitivity of CRC. He et al (181) performed microarray analysis on CRC-resistant cells and reported that
Wnt signaling activation leads to 5-FU resistance via inhibition of the CHK1 pathway in TP53 wild-type cells, such as HCT-8. In addition, period circadian protein homolog 3 and dishevelled-3 are common members of the $\mathrm{Wnt} / \beta$-catenin pathway and the Notch signaling pathway, which are involved in chemoresistance (182). Experimental inhibition or enhancement of the expression of these genes act on the $\mathrm{Wnt} / \beta$-catenin signaling and Notch signaling pathways simultaneously to improve drug sensitivity $(182,183)$. These findings highlight the fact that the Wnt/ $\beta$-catenin signaling pathway and other signaling pathways exhibit crosstalk, synergistic and antagonistic effects in the occurrence of CRC resistance. Common members between these different signaling pathways should be identified as targets to overcome the occurrence of CRC resistance.

\section{Conclusions}

CRC is one of the most common malignant tumors in humans, and the survival rate remains low (1). Treatment resistance in CRC remains an unsolved problem (17). Generally, the chemical resistance mechanism of CRC is closely associated with CSCs, ncRNAs and the TME (19-22). Wnt/ $\beta$-catenin signaling maintains the natural chemical resistance of CSCs and improves drug resistance via the promotion of ABC transporter and glycolysis in CSCs cells $(25,119)$. The interaction between Wnt/ $\beta$-catenin signaling and ncRNAs regulates the cell cycle and the expression of cancer-related genes $(26,131,132)$. The TME enhances $W n t / \beta$-catenin 
signaling activity (150). Wnt/ $\beta$-catenin signaling also mediates tumor immune escape in the TME (151). Therefore, examining the role of $\mathrm{Wnt} / \beta$-catenin signaling in depth has great potential for therapeutic intervention. More studies should focus on the mechanism of CRC resistance, and robust preclinical drug testing of Wnt inhibitors as a single drug or in combination with CRC is required.

\section{Acknowledgements}

Not applicable.

\section{Funding}

This study was supported by grants from the Natural Science Foundation of Jiangxi Province (grant no. 20202BABL206089) and the Natural Science Foundation of Department of Education of Jiangxi Province (grant no. GJJ190072).

\section{Availability of data and materials}

Not applicable.

\section{Authors' contributions}

GXZ, ZZS, LC and WJD collected the related literature and drafted the manuscript. QFY and DG participated in the design of the review and drafted the manuscript. All authors read and approved the final manuscript.

\section{Ethics approval and consent to participate}

Not applicable.

\section{Patient consent for publication}

Not applicable.

\section{Competing interests}

The authors declare that they have no competing interests.

\section{References}

1. Keum N and Giovannucci E: Global burden of colorectal cancer: Emerging trends, risk factors and prevention strategies. Nat Rev Gastroenterol Hepatol 16: 713-732, 2019.

2. Rawla P, Sunkara T and Barsouk A: Epidemiology of colorectal cancer: Incidence, mortality, survival, and risk factors. Prz Gastroenterol 14: 89-103, 2019.

3. Arnold M, Sierra MS, Laversanne M, Soerjomataram I, Jemal A and Bray F: Global patterns and trends in colorectal cancer incidence and mortality. Gut 66: 683-691, 2017.

4. Marmol I, Sanchez-de-Diego C, Pradilla Dieste A, Cerrada E and Rodriguez Yoldi MJ: Colorectal carcinoma: A general overview and future perspectives in colorectal cancer. Int J Mol Sci 18: 197, 2017.

5. Calvert PM and Frucht H: The genetics of colorectal cancer. Ann Intern Med 137: 603-612, 2002.

6. Angarita FA, Feinberg AE, Feinberg SM, Riddell RH and McCart JA: Management of complex polyps of the colon and rectum. Int J Colorectal Dis 33: 115-129, 2018.

7. Blank A, Roberts DE II, Dawson H, Zlobec I and Lugli A: Tumor heterogeneity in primary colorectal cancer and corresponding metastases. Does the apple fall far from the tree? Front Med (Lausanne) 5: 234, 2018.
8. Dahmus JD, Kotler DL, Kastenberg DM and Kistler CA: The gut microbiome and colorectal cancer: A review of bacterial pathogenesis. J Gastrointest Oncol 9: 769-777, 2018.

9. Jayasekara H, English DR, Haydon A, Hodge AM, Lynch BM, Rosty C, Williamson EJ, Clendenning M, Southey MC, Jenkins MA, et al: Associations of alcohol intake, smoking, physical activity and obesity with survival following colorectal cancer diagnosis by stage, anatomic site and tumor molecular subtype. Int J Cancer 142: 238-250, 2018.

10. Mehta A and Patel BM: Therapeutic opportunities in colon cancer: Focus on phosphodiesterase inhibitors. Life Sci 230: 150-161, 2019.

11. Salonga D, Danenberg KD, Johnson M, Metzger R, Groshen S, Tsao-Wei DD, Lenz HJ, Leichman CG, Leichman L, Diasio RB and Danenberg PV: Colorectal tumors responding to 5-fluorouracil have low gene expression levels of dihydropyrimidine dehydrogenase, thymidylate synthase, and thymidine phosphorylase. Clin Cancer Res 6: 1322-1327, 2000.

12. Showalter SL, Showalter TN, Witkiewicz A, Havens R, Kennedy EP, Hucl T, Kern SE, Yeo CJ and Brody JR: Evaluating the drug-target relationship between thymidylate synthase expression and tumor response to 5-fluorouracil. Is it time to move forward? Cancer Biol Ther 7: 986-994, 2008.

13. Yaffee P, Osipov A, Tan C, Tuli R and Hendifar A: Review of systemic therapies for locally advanced and metastatic rectal cancer. J Gastrointest Oncol 6: 185-200, 2015.

14. Cunningham D, Humblet Y, Siena S, Khayat D, Bleiberg H, Santoro A, Bets D, Mueser M, Harstrick A, Verslype C, et al: Cetuximab monotherapy and cetuximab plus irinotecan in irinotecan-refractory metastatic colorectal cancer. N Engl J Med 351: 337-345, 2004.

15. Van Cutsem E, Peeters M, Siena S, Humblet Y, Hendlisz A, Neyns B, Canon JL, Van Laethem JL, Maurel J, Richardson G, et al: Open-label phase III trial of panitumumab plus best supportive care compared with best supportive care alone in patients with chemotherapy-refractory metastatic colorectal cancer. J Clin Oncol 25: 1658-1664, 2007.

16. $\mathrm{Hu}$ T, Li Z, Gao CY and Cho CH: Mechanisms of drug resistance in colon cancer and its therapeutic strategies. World J Gastroenterol 22: 6876-6889, 2016.

17. Li YJ, Lei YH, Yao N, Wang CR, Hu N, Ye WC, Zhang DM and Chen ZS: Autophagy and multidrug resisitance in cancer. Chin J Cancer 36: 52, 2017.

18. Thomas $\mathrm{H}$ and Coley HM: Overcoming multidrug resistance in cancer: An update on the clinical strategy of inhibiting p-glycoprotein. Cancer Control 10: 159-165, 2003.

19. Tredan O, Galmarini CM, Patel K and Tannock IF: Drug resistance and the solid tumor microenvironment. J Natl Cancer Inst 99: 1441-1454, 2007.

20. Wang MY, Qiu YH, Cai ML, Zhang CH, Wang XW, Liu H, Chen Y, Zhao WL, Liu JB and Shao RG: Role and molecular mechanism of stem cells in colorectal cancer initiation. J Drug Target 28: 1-10, 2020.

21. Liu X, Fu Q, Du Y, Yang Y and Cho WC: MicroRNA as regulators of cancer stem cells and chemoresistance in colorectal cancer. Curr Cancer Drug Targets 16: 738-754, 2016.

22. Fanale D, Barraco N, Listi A, Bazan V and Russo A: Non-coding RNAs functioning in colorectal cancer stem cells. Adv Exp Med Biol 937: 93-108, 2016.

23. Rahmani F, Avan A, Hashemy SI and Hassanian SM: Role of Wnt/beta-catenin signaling regulatory microRNAs in the pathogenesis of colorectal cancer. J Cell Physiol 233: 811-817, 2018.

24. Das PK, Islam F and Lam AK: The roles of cancer stem cells and therapy resistance in colorectal carcinoma. Cells 9: 1392, 2020.

25. Chikazawa N, Tanaka H, Tasaka T, Nakamura M, Tanaka M, Onishi $\mathrm{H}$ and Katano M: Inhibition of Wnt signaling pathway decreases chemotherapy-resistant side-population colon cancer cells. Anticancer Res 30: 2041-2048, 2010.

26. Shi L, Xi J, Xu X, Peng B and Zhang B: MiR-148a suppressed cell invasion and migration via targeting WNT10b and modulating $\beta$-catenin signaling in cisplatin-resistant colorectal cancer cells. Biomed Pharmacother 109: 902-909, 2019.

27. Hu YB, Yan C, Mu L, Mi YL, Zhao H, Hu H, Li XL, Tao DD, Wu YQ, Gong JP and Qin JC: Exosomal Wnt-induced dedifferentiation of colorectal cancer cells contributes to chemotherapy resistance. Oncogene 38: 1951-1965, 2019.

28. Nusse R and Varmus HE: Many tumors induced by the mouse mammary tumor virus contain a provirus integrated in the same region of the host genome. Cell 31: 99-109, 1982. 
29. Rijsewijk F, Schuermann M, Wagenaar E, Parren P, Weigel D and Nusse R: The Drosophila homolog of the mouse mammary oncogene int-1 is identical to the segment polarity gene wingless. Cell 50: 649-657, 1987.

30. Kahn M: Can we safely target the WNT pathway? Nat Rev Drug Discov 13: 513-532, 2014

31. Zeng ZY, Zhou YH, Zhang WL, Xiong W, Fan SQ, Li XL, Luo XM, Wu MH, Yang YX, Huang C, et al: Gene expression profiling of nasopharyngeal carcinoma reveals the abnormally regulated Wnt signaling pathway. Hum Pathol 38: 120-133, 2007.

32. Pate KT, Stringari C, Sprowl-Tanio S, Wang K, TeSlaa T, Hoverter NP, McQuade MM, Garner C, Digman MA, Teitell MA, et al: Wnt signaling directs a metabolic program of glycolysis and angiogenesis in colon cancer. EMBO J 33: 1454-1473, 2014.

33. Polakis P: Wnt signaling in cancer. Cold Spring Harb Perspect Biol 4: a008052, 2012.

34. Tammela T, Sanchez-Rivera FJ, Cetinbas NM, Wu K, Joshi NS, Helenius K, Park Y, Azimi R, Kerper NR, Wesselhoeft RA, et al: A Wnt-producing niche drives proliferative potential and progression in lung adenocarcinoma. Nature 545: 355-359, 2017.

35. Lee SY, Jeon HM, Ju MK, Kim CH, Yoon G, Han SI, Park HG and Kang HS: Wnt/Snail signaling regulates cytochrome C oxidase and glucose metabolism. Cancer Res 72: 3607-3617, 2012.

36. Willert K, Brown JD, Danenberg E, Duncan AW, Weissman IL, Reya T, Yates JR III and Nusse R: Wnt proteins are lipid-modified and can act as stem cell growth factors. Nature 423: 448-452, 2003.

37. Takada R, Satomi Y, Kurata T, Ueno N, Norioka S, Kondoh H, Takao T and Takada S: Monounsaturated fatty acid modification of Wnt protein: Its role in Wnt secretion. Dev Cell 11: 791-801, 2006.

38. He B, You L, Uematsu K, Xu Z, Lee AY, Matsangou M, McCormick F and Jablons DM: A monoclonal antibody against Wnt-1 induces apoptosis in human cancer cells. Neoplasia 6: $7-14,2004$

39. Chen G, Shukeir N, Potti A, Sircar K, Aprikian A, Goltzman D and Rabbani SA: Up-regulation of Wnt-1 and beta-catenin production in patients with advanced metastatic prostate carcinoma: Potential pathogenetic and prognostic implications. Cancer 101: 1345-1356, 2004.

40. Babaei K, Khaksar R, Zeinali T, Hemmati H, Bandegi A, Samidoust P, Ashoobi MT, Hashemian H, Delpasand K, Talebinasab F, et al: Epigenetic profiling of MUTYH, KLF6, WNT1 and KLF4 genes in carcinogenesis and tumorigenesis of colorectal cancer. Biomedicine (Taipei) 9: 22, 2019.

41. Jia S, Qu T, Feng M, Ji K, Li Z, Jiang W and Ji J: Association of Wnt1-inducible signaling pathway protein-1 with the proliferation, migration and invasion in gastric cancer cells. Tumour Biol 39: 1010428317699755, 2017.

42. Bodnar L, Stanczak A, Cierniak S, Smoter M, Cichowicz M, KozlowskiW,SzczylikC,WieczorekMandLamparska-PrzybyszM: Wnt/ $\beta$-catenin pathway as a potential prognostic and predictive marker in patients with advanced ovarian cancer. J Ovarian Res 7 16, 2014.

43. Huang CB, Ma RJ, Xu Y, Li N, Li ZX, Yue J, Li HX, Guo Y and Qi D: Wnt2 promotes non-small cell lung cancer progression by activating WNT/ $\beta$-catenin pathway. Am J Cancer Res 5: 1032-1046, 2015.

44. Katoh M: Frequent up-regulation of WNT2 in primary gastric cancer and colorectal cancer. Int J Oncol 19: 1003-1007, 2001

45. Nakashima $N$, Liu D, Huang CL, Ueno $M$, Zhang $X$ and Yokomise $\mathrm{H}$ : Wnt3 gene expression promotes tumor progression in non-small cell lung cancer. Lung Cancer 76: 228-234, 2012.

46. Wang HS, Nie X, Wu RB, Yuan HW, Ma YH, Liu XL, Zhang JY, Deng XL, Na Q, Jin HY, et al: Downregulation of human Wnt3 in gastric cancer suppresses cell proliferation and induces apoptosis. Onco Targets Ther 9: 3849-3860, 2016

47. Nie XB, Xia FL, Liu Y, Zhou Y, Ye WL, Hean PH, Meng JM, Liu HY, Liu L, Wen JX, et al: Downregulation of Wnt3 suppresses colorectal cancer development through inhibiting cell proliferation and migration. Front Pharmacol 10: 1110, 2019.

48. Thiago L, Costa ES, Lopes DV, Otazu IB, Nowill AE, Mendes FA, Portilho DM, Abreu JG, Mermelstein CS, Orfao A, et al: The Wnt signaling pathway regulates Nalm-16 b-cell precursor acute lymphoblastic leukemic cell line survival and etoposide resistance. Biomed Pharmacother 64: 63-72, 2010.

49. Zimmerman ZF, Kulikauskas RM, Bomsztyk K, Moon RT and Chien AJ: Activation of Wnt/ $\beta$-catenin signaling increases apoptosis in melanoma cells treated with trail. PLoS One 8: e69593, 2013.
50. Annavarapu SR, Cialfi S, Dominici C, Kokai GK, Uccini S, Ceccarelli S, McDowell HP and Helliwell TR: Characterization of Wnt/ $\beta$-catenin signaling in rhabdomyosarcoma. Lab Invest 93: 1090-1099, 2013

51. Fox SA, Richards AK, Kusumah I, Perumal V, Bolitho EM, Mutsaers SE and Dharmarajan AM: Expression profile and function of Wnt signaling mechanisms in malignant mesothelioma cells. Biochem Biophys Res Commun 440: 82-87, 2013.

52. Wang SH, Li N, Wei Y, Li QR and Yu ZP: $\beta$-catenin deacetylation is essential for WNT-induced proliferation of breast cancer cells. Mol Med Rep 9: 973-978, 2014.

53. Akaboshi S, Watanabe S, Hino Y, Sekita Y, Xi Y, Araki K, Yamamura K, Oshima M, Ito T, Baba H and Nakao M: HMGA1 is induced by Wnt/beta-catenin pathway and maintains cell proliferation in gastric cancer. Am J Pathol 175: 1675-1685, 2009.

54. Zhao L, Wang LL, Zhang CL, Liu Z, Piao YJ, Yan J, Xiang R, Yao YQ and Y S: E6-induced selective translation of WNT4 and JIP2 promotes the progression of cervical cancer via a noncanonical WNT signaling pathway. Signal Transduct Target Ther 4: 32, 2019.

55. McDonald SL and Silver A: The opposing roles of Wnt-5a in cancer. Br J Cancer 101: 209-214, 2009.

56. Li J, Ying J, Fan Y, Wu L, Ying Y, Chan AT, Srivastava G and Tao Q: WNT5A antagonizes WNT/ $\beta$-catenin signaling and is frequently silenced by promoter $\mathrm{CpG}$ methylation in esophageal squamous cell carcinoma. Cancer Biol Ther 10: 617-624, 2010.

57. Ying J, Li H, Yu J, Ng KM, Poon FF, Wong SC, Chan AT, Sung JJ and Tao Q: WNT5A exhibits tumor-suppressive activity through antagonizing the Wnt/beta-catenin signaling, and is frequently methylated in colorectal cancer. Clin Cancer Res 14: 55-61, 2008.

58. Kremenevskaja N, von Wasielewski R, Rao AS, Schofl C, Andersson T and Brabant G: Wnt-5a has tumor suppressor activity in thyroid carcinoma. Oncogene 24: 2144-2154, 2005.

59. Thiele S, Rachner TD, Rauner M and Hofbauer LC: WNT5A and its receptors in the bone-cancer dialogue. J Bone Miner Res 31: 1488-1496, 2016.

60. Kurayoshi M, Oue N, Yamamoto H, Kishida M, Inoue A, Asahara T, Yasui W and Kikuchi A: Expression of Wnt-5a is correlated with aggressiveness of gastric cancer by stimulating cell migration and invasion. Cancer Res 66: 10439-10448, 2006.

61. Huang CL, Liu D, Nakano J, Ishikawa S, Kontani K, Yokomise H and Ueno M: Wnt5a expression is associated with the tumor proliferation and the stromal vascular endothelial growth factor-an expression in non-small-cell lung cancer. J Clin Oncol 23: 8765-8773, 2005.

62. Bo H, Zhang S, Gao L, Chen Y, Zhang J, Chang X and Zhu M: Upregulation of Wnt5a promotes epithelial-tomesenchymal transition and metastasis of pancreatic cancer cells. BMC Cancer 13: 496, 2013.

63. Navarrete-Meneses MDP and Perez-Vera P: Epigenetic alterations in acute lymphoblastic leukemia. Bol Med Hosp Infant Mex 74: 243-264, 2017 (In Spanish).

64. Stewart DJ: Wnt signaling pathway in non-small cell lung cancer. J Natl Cancer Inst 106: djt356, 2014.

65. Kirikoshi H and Katoh M: Expression of WNT7A in human normal tissues and cancer, and regulation of WNT7A and WNT7B in human cancer. Int J Oncol 21: 895-900, 2002.

66. Vesel M, Rapp J, Feller D, Kiss E, Jaromi L, Meggyes M, Miskei G, Duga B, Smuk G, Laszlo T, et al: ABCB1 and ABCG2 drug transporters are differentially expressed in non-small cell lung cancers (NSCLC) and expression is modified by cisplatin treatment via altered Wnt signaling. Respir Res 18: 52, 2017.

67. Li J, Zhang Z, Wang L and Zhang Y: The oncogenic role of Wnt10a in colorectal cancer through activation of canonical Wnt// -catenin signaling. Oncol Lett 17: 3657-3664, 2019.

68. Li P, Liu W, Xu Q and Wang C: Clinical significance and biological role of Wnt10a in ovarian cancer. Oncol Lett 14: 6611-6617, 2017.

69. Hsu RJ, Ho JY, Cha TL, Yu DS, Wu CL, Huang WP, Chu P, Chen YH, Chen JT and Yu CP: WNT10A plays an oncogenic role in renal cell carcinoma by activating WNT/beta-catenin pathway. PLoS One 7: e47649, 2012.

70. Kirikoshi H, Inoue S, Sekihara $\mathrm{H}$ and Katoh M: Expression of WNT10A in human cancer. Int J Oncol 19: 997-1001, 2001

71. Dong T, Zhang Z, Zhou W, Zhou X, Geng C, Chang LK, Tian X and Liu S: WNT10A/ $\beta$-catenin pathway in tumorigenesis of papillary thyroid carcinoma. Oncol Rep 38: 1287-1294, 2017.

72. Wend P, Runke S, Wend K, Anchondo B, Yesayan M, Jardon M, Hardie N, Loddenkemper C, Ulasov I, Lesniak MS, et al: WNT10B/beta-catenin signalling induces HMGA2 and proliferation in metastatic triple-negative breast cancer. EMBO Mol Med 5: 264-279, 2013. 
73. Chen H, Wang Y and Xue F: Expression and the clinical significance of Wnt10a and Wnt 10b in endometrial cancer are associated with the Wnt/ß-catenin pathway. Oncol Rep 29: 507-514, 2013.

74. Saitoh T, Kirikoshi H, Mine T and Katoh M: Proto-oncogene WNT10B is up-regulated by tumor necrosis factor alpha in human gastric cancer cell line MKN45. Int J Oncol 19: 1187-1192, 2001.

75. Bartis D, Csongei V, Weich A, Kiss E, Barko S, Kovacs T, Avdicevic M,D'Souza VK, RappJ,Kvell K, et al: Down-regulation of canonical and up-regulation of non-canonical Wnt signalling in the carcinogenic process of squamous cell lung carcinoma. PLoS One 8: e57393, 2013.

76. Tian S, Hu J, Tao K, Wang J, Chu Y, Li J, Liu Z, Ding X, Xu L, Li Q, et al: Secreted AGR2 promotes invasion of colorectal cancer cells via Wnt11-mediated non-canonical Wnt signaling. Exp Cell Res 364: 198-207, 2018.

77. Toyama T, Lee HC, Koga H, Wands JR and Kim M: Noncanonical Wnt11 inhibits hepatocellular carcinoma cell proliferation and migration. Mol Cancer Res 8: 254-265, 2010.

78. Yin $\mathrm{P}$, Wang W, Zhang Z, Bai Y, Gao J and Zhao C: Wnt signaling in human and mouse breast cancer: Focusing on Wnt ligands, receptors and antagonists. Cancer Sci 109: 3368-3375, 2018.

79. Barker N, van Es JH, Kuipers J, Kujala P, van den Born M, Cozijnsen M, Haegebarth A, Korving J, Begthel H, Peters PJ and Clevers H: Identification of stem cells in small intestine and colon by marker gene Lgr5. Nature 449: 1003-1007, 2007.

80. Bourroul GM, Fragoso HJ, Gomes JW, Bourroul VS, Oshima CT, Gomes TS, Saba GT, Palma RT and Waisberg J: The destruction complex of beta-catenin in colorectal carcinoma and colonic adenoma. Einstein (Sao Paulo) 14: 135-142, 2016.

81. Sawa M, Masuda M and Yamada T: Targeting the Wnt signaling pathway in colorectal cancer. Expert Opin Ther Targets 20 419-429, 2016.

82. Amit S, Hatzubai A, Birman Y, Andersen JS, Ben-Shushan E, Mann M, Ben-Neriah Y and Alkalay I: Axin-mediated CKI phosphorylation of beta-catenin at Ser 45: A molecular switch for the Wnt pathway. Genes Dev 16: 1066-1076, 2002.

83. He X, Semenov M, Tamai K and Zeng X: LDL receptor-related proteins 5 and 6 in Wnt/beta-catenin signaling: Arrows point the way. Development 131: 1663-1677, 2004.

84. Bilic J, Huang YL, Davidson G, Zimmermann T, Cruciat CM, Bienz $M$ and Niehrs C: Wnt induces LRP6 signalosomes and promotes dishevelled-dependent LRP6 phosphorylation. Science 316: 1619-1622, 2007.

85. Zarkou V, Galaras A, Giakountis A and Hatzis P: Crosstalk mechanisms between the WNT signaling pathway and long non-coding RNAs. Noncoding RNA Res 3: 42-53, 2018.

86. Hammond WA, Swaika A and Mody K: Pharmacologic resistance in colorectal cancer: A review. Ther Adv Med Oncol 8 : 57-84, 2016.

87. Gheidari F, Bakhshandeh B, Teimoori-Toolabi L, Mehrtash A, Ghadir M and Zeinali S: TCF4 silencing sensitizes the colon cancer cell line to oxaliplatin as a common chemotherapeutic drug. Anticancer Drugs 25: 908-916, 2014.

88. Kosuri KV, Wu X, Wang L, Villalona-Calero MA and Otterson GA: An epigenetic mechanism for capecitabine resistance in mesothelioma. Biochem Biophys Res Commun 391: $1465-1470,2010$

89. Rieth J and Subramanian S: Mechanisms of intrinsic tumor resistance to immunotherapy. Int J Mol Sci 19: 1340, 2018.

90. Ghadimi BM, Grade M, Difilippantonio MJ, Varma S, Simon R, Montagna C, Fuzesi L, Langer C, Becker H, Liersch T and Ried T: Effectiveness of gene expression profiling for response prediction of rectal adenocarcinomas to preoperative chemoradiotherapy. J Clin Oncol 23: 1826-1838, 2005.

91. Emons G, Spitzner M, Reineke S, Moller J, Auslander N, Kramer F, Hu Y, Beissbarth T, Wolff HA, Rave-Frank M, et al: Chemoradiotherapy resistance in colorectal cancer cells is mediated by Wnt/beta-catenin signaling. Mol Cancer Res 15 : 1481-1490, 2017

92. Deng YH, Pu XX, Huang MJ, Xiao J, Zhou JM, Lin TY and Lin EH: 5-Fluorouracil upregulates the activity of Wnt signaling pathway in CD133-positive colon cancer stem-like cells. Chin J Cancer 29: 810-815, 2010

93. Vaish V, Kim J and Shim M: Jagged-2 (JAG2) enhances tumorigenicity and chemoresistance of colorectal cancer cells. Oncotarget 8: 53262-53275, 2017.

94. Kukcinaviciute E, Jonusiene V, Sasnauskiene A, Dabkeviciene D Eidenaite E and Laurinavicius A: Significance of Notch and Wnt signaling for chemoresistance of colorectal cancer cells HCT116. J Cell Biochem 119: 5913-5920, 2018.
95. Gonzalez-Exposito R, Semiannikova M, Griffiths B, Khan K, Barber LJ, Woolston A, Spain G, von Loga K, Challoner B, Patel R, et al: CEA expression heterogeneity and plasticity confer resistance to the CEA-targeting bispecific immunotherapy antibody cibisatamab (CEA-TCB) in patient-derived colorectal cancer organoids. J Immunother Cancer 7: 101, 2019.

96. Chang TC, Yeh CT, Adebayo BO, Lin YC, Deng L, Rao YK, Huang CC, Lee WH, Wu AT, Hsiao M, et al: 4-Acetylantroquinonol B inhibits colorectal cancer tumorigenesis and suppresses cancer stem-like phenotype. Toxicol Appl Pharmacol 288: 258-268, 2015.

97. Vermeulen L, Sprick MR, Kemper K, Stassi G and Medema JP Cancer stem cells-old concepts, new insights. Cell Death Differ 15: 947-958, 2008

98. Munro MJ, Wickremesekera SK, Peng L, Tan ST and Itinteang T: Cancer stem cells in colorectal cancer: A review. J Clin Pathol 71: 110-116, 2018.

99. Li N, Babaei-Jadidi R, Lorenzi F, Spencer-Dene B, Clarke P, Domingo E, Tulchinsky E, Vries RGJ, Kerr D, Pan Y, et al: An FBXW7-ZEB2 axis links EMT and tumour microenvironment to promote colorectal cancer stem cells and chemoresistance. Oncogenesis 8: 13, 2019.

100. Prieti-Vila M, Takahashi R, Usuba W, Kohama I and Ochiya T: Drug resistance driven by cancer stem cells and their niche. Int J Mol Sci 18: 2574, 2017.

101. Li L and Xie T: Stem cell niche: Structure and function. Annu Rev Cell Dev Biol 21: 605-631, 2005.

102. Liu H, Zhang W, Jia Y, Yu Q, Grau GE, Peng L, Ran Y, Yang Z, Deng $\mathrm{H}$ and Lou J: Single-cell clones of liver cancer stem cells have the potential of differentiating into different types of tumor cells. Cell Death Dis 4: e857, 2013.

103. Daverey A, Drain AP and Kidambi S: Physical intimacy of breast cancer cells with mesenchymal stem cells elicits trastuzumab resistance through src activation. Sci Rep 5: 13744, 2015.

104. Kim JY, Lee HY, Park KK, Choi YK, Nam JS and Hong IS CWP232228 targets liver cancer stem cells through Wnt/ $\beta$-catenin signaling: A novel therapeutic approach for liver cancer treatment. Oncotarget 7: 20395-20409, 2016.

105. Fevr T, Robine S, Louvard D and Huelsken J: Wnt/beta-catenin is essential for intestinal homeostasis and maintenance of intestinal stem cells. Mol Cell Biol 27: 7551-7559, 2007.

106. Dahal Lamichane B, Jung SY, Yun J, Kang S, Kim DY, Lamichane S, Kim YJ, Park JH, Jang WB, Ji ST, et al: AGR2 is a target of canonical Wnt/ $\beta$-catenin signaling and is important for stemness maintenance in colorectal cancer stem cells. Biochem Biophys Res Commun 515: 600-606, 2019.

107. Liu YS, Hsu HC, Tseng KC, Chen HC and Chen SJ: Lgr5 promotes cancer stemness and confers chemoresistance through ABCB1 in colorectal cancer. Biomed Pharmacother 67: 791-799, 2013.

108. Zhan T, Ambrosi G, Wandmacher AM, Rauscher B, Betge J, Rindtorff N, Haussler RS, Hinsenkamp I, Bamberg L, Hessling B, et al: MEK inhibitors activate Wnt signalling and induce stem cell plasticity in colorectal cancer. Nat Commun 10: 2197,2019

109. Wu W, Cao J, Ji Z, Wang J, Jiang T and Ding H: Co-expression of Lgr5 and CXCR4 characterizes cancer stem-like cells of colorectal cancer. Oncotarget 7: 81144-81155, 2016.

110. Kobayashi S, Yamada-Okabe H, Suzuki M, Natori O, Kato A, Matsubara K, Jau Chen Y, Yamazaki M, Funahashi S, Yoshida K, et al: LGR5-positive colon cancer stem cells interconvert with drug-resistant LGR5-negative cells and are capable of tumor reconstitution. Stem Cells 30: 2631-2644, 2012.

111. Villanueva-Toledo J, Ponciano-Gomez A, Ortiz-Sanchez E and Garrido E: Side populations from cervical-cancer-derived cell lines have stem-cell-like properties. Mol Biol Rep 41: 1993-2004, 2014.

112. Steinbichler TB, Dudas J, Skvortsov S, Ganswindt U, Riechelmann $\mathrm{H}$ and Skvortsova II: Therapy resistance mediated by cancer stem cells. Semin Cancer Biol 53: 156-167, 2018.

113. Singh A and Settleman J: EMT, cancer stem cells and drug resistance: An emerging axis of evil in the war on cancer. Oncogene 29: 4741-4751, 2010.

114. Martin-Orozco E, Sanchez-Fernandez A, Ortiz-Parra I and Ayala-San Nicolas M: WNT signaling in tumors: The way to evade drugs and immunity. Front Immunol 10: 2854, 2019.

115. Islam MO, Kanemura Y, Tajria J, Mori H, Kobayashi S, Shofuda T, Miyake J, Hara M, Yamasaki M and Okano H: Characterization of $\mathrm{ABC}$ transporter $\mathrm{ABCB} 1$ expressed in human neural stem/progenitor cells. FEBS Lett 579: 3473-3480, 2005. 
116. Falasca $\mathrm{M}$ and Linton $\mathrm{KJ}$ : Investigational $\mathrm{ABC}$ transporter inhibitors. Expert Opin Investig Drugs 21: 657-666, 2012.

117. Duan Z, Li X, Huang H, Yuan W, Zheng SL, Liu X, Zhang Z, Choy E, Harmon D, Mankin H and Hornicek F: Synthesis and evaluation of (2-(4-methoxyphenyl)-4-quinolinyl)(2-piperidinyl)methanol (NSC23925) isomers to reverse multidrug resistance in cancer. J Med Chem 55: 3113-3121, 2012.

118. Huang XC, Sun YL, Salim AA, Chen ZS and Capon RJ: Parguerenes: Marine red alga bromoditerpenes as inhibitors of P-glycoprotein (ABCB1) in multidrug resistant human cancer cells. Biochem Pharmacol 85: 1257-1268, 2013.

119. Zinzi L, Contino M, Cantore M, Capparelli E, Leopoldo M and Colabufo NA: ABC transporters in CSCs membranes as a novel target for treating tumor relapse. Front Pharmacol 5: 163, 2014.

120. Liu YY, Gupta V, Patwardhan GA, Bhinge K, Zhao Y, Bao J, Mehendale H, Cabot MC, Li YT and Jazwinski SM: Glucosylceramide synthase upregulates MDR1 expression in the regulation of cancer drug resistance through $\mathrm{cSrc}$ and beta-catenin signaling. Mol Cancer 9: 145, 2010.

121. Kugimiya N, Nishimoto A, Hosoyama T, Ueno K, Enoki T Li TS and Hamano K: The c-MYC-ABCB5 axis plays a pivotal role in 5-fluorouracil resistance in human colon cancer cells. J Cell Mol Med 19: 1569-1581, 2015.

122. Wang T, Chen Z, Zhu Y, Pan Q, Liu Y, Qi X, Jin L, Jin J, Ma X and Hua D: Inhibition of transient receptor potential channel 5 reverses 5-Fluorouracil resistance in human colorectal cancer cells. J Biol Chem 290: 448-456, 2015.

123. Plaks V, Kong N and Werb Z: The cancer stem cell niche: How essential is the niche in regulating stemness of tumor cells? Cell Stem Cell 16: 225-238, 2015.

124. Osthus RC, Shim H, Kim S, Li Q, Reddy R, Mukherjee M, Xu Y, Wonsey D, Lee LA and Dang CV: Deregulation of glucose transporter 1 and glycolytic gene expression by c-Myc. J Biol Chem 275: 21797-21800, 2000.

125. Wang T, Ning K, Lu TX and Hua D: Elevated expression of TrpC5 and GLUT1 is associated with chemoresistance in colorectal cancer. Oncol Rep 37: 1059-1065, 2017.

126. Matsui M and Corey DR: Non-coding RNAs as drug targets. Nat Rev Drug Discov 16: 167-179, 2017.

127. Ling H, Fabbri $M$ and Calin GA: MicroRNAs and other non-coding RNAs as targets for anticancer drug development. Nat Rev Drug Discov 12: 847-865, 2013.

128. Laurent GS, Wahlestedt C and Kapranov P: The landscape of long noncoding RNA classification. Trends Genet 31: 239-251, 2015 .

129. Sato-Kuwabara Y, Melo SA, Soares FA and Calin GA: The fusion of two worlds: Non-coding RNAs and extracellular vesicles-diagnostic and therapeutic implications (Review). Int J Oncol 46: 17-27, 2015.

130. Ebbesen KK, Kjems J and Hansen TB: Circular RNAs: Identification, biogenesis and function. Biochim Biophys Acta 1859: 163-168, 2016.

131. Chen HY, Lang YD, Lin HN, Liu YR, Liao CC, Nana AW, Yen Y and Chen RH: miR-103/107 prolong Wnt/ $\beta$-catenin signaling and colorectal cancer stemness by targeting Axin2. Sci Rep 9: 9687, 2019.

132. Zhou H, Lin C, Zhang Y, Zhang X, Zhang C, Zhang P, Xie X and Ren Z: miR-506 enhances the sensitivity of human colorectal cancer cells to oxaliplatin by suppressing MDR1/P-gp expression. Cell Prolif 50: e12341, 2017.

133. Lu ML, Zhang Y, Li J, Fu Y, Li WH, Zhao GF, Li XH, Wei L, Liu GB and Huang H: MicroRNA-124 inhibits colorectal cancer cell proliferation and suppresses tumor growth by interacting with PLCB1 and regulating Wnt/ $\beta$-catenin signaling pathway. Eur Rev Med Pharmacol Sci 23: 121-136, 2019.

134. Liang CQ, Fu YM, Liu ZY, Xing BR, Jin Y and Huang JL: The effect of miR-224 down-regulation on SW80 cell proliferation and apoptosis and weakening of ADM drug resistance. Eur Rev Med Pharmacol Sci 21: 5008-5016, 2017.

135. Lucero OM, Dawson DW, Moon RT and Chien AJ: A re-evaluation of the 'oncogenic' nature of Wnt/beta-catenin signaling in melanoma and other cancers. Curr Oncol Rep 12: 314-318, 2010

136. Song C, Lu P, Sun G, Yang L, Wang Z and Wang Z: miR-34a sensitizes lung cancer cells to cisplatin via $553 / \mathrm{miR}-34 \mathrm{a} / \mathrm{MYCN}$ axis. Biochem Biophys Res Commun 482: 22-27, 2017.

137. Schulz-Heddergott R, Stark N, Edmunds SJ, Li J, Conradi LC, Bohnenberger H, Ceteci F, Greten FR, Dobbelstein M and Moll UM: Therapeutic ablation of gain-of-function mutant p53 in colorectal cancer inhibits stat3-mediated tumor growth and invasion. Cancer Cell 34: 298-314 e297, 2018.
138. Nakayama M, Sakai E, Echizen K, Yamada Y, Oshima H, Han TS, Ohki R, Fujii S, Ochiai A, Robine S, et al: Intestinal cancer progression by mutant p53 through the acquisition of invasiveness associated with complex glandular formation. Oncogene 36: 5885-5896, 2017.

139. Lane DP, Cheok CF and Lain S: p53-based cancer therapy. Cold Spring Harb Perspect Biol 2: a001222, 2010

140. Tsou SH, Hou MH, Hsu LC, Chen TM and Chen $\mathrm{YH}$ : Gain-of-function p53 mutant with 21-bp deletion confers susceptibility to multidrug resistance in MCF-7 cells. Int J Mol Med 37: 233-242, 2016

141. Li XL, Zhou J, Chen ZR and Chng WJ: P53 mutations in colorectal cancer-molecular pathogenesis and pharmacological reactivation. World J Gastroenterol 21: 84-93, 2015.

142. Kwak B, Kim DU, Kim TO, Kim HS and Kim SW: MicroRNA-552 links Wnt signaling to 553 tumor suppressor in colorectal cancer. Int J Oncol 53: 1800-1808, 2018.

143. Zhou AD, Diao LT, Xu H, Xiao ZD, Li JH, Zhou H and Qu LH: $\beta$-Catenin/LEF1 transactivates the microRNA-371-373 cluster that modulates the Wnt/ $\beta$-catenin-signaling pathway. Oncogene 31: 2968-2978, 2012.

144. Wang LQ, Yu P, Li B, Guo YH, Liang ZR, Zheng LL, Yang JH, $\mathrm{Xu} \mathrm{H}$, Liu S, Zheng LS, et al: miR-372 and miR-373 enhance the stemness of colorectal cancer cells by repressing differentiation signaling pathways. Mol Oncol 12: 1949-1964, 2018.

145. Han P, Li JW, Zhang BM, Lv JC, Li YM, Gu XY, Yu ZW, Jia YH, Bai XF, Li L, et al: The lncRNA CRNDE promotes colorectal cancer cell proliferation and chemoresistance via miR-181a-5p-mediated regulation of $\mathrm{Wnt} / \beta$-catenin signaling. Mol Cancer 16: 9, 2017.

146. Xiao Z, Qu Z, Chen Z, Fang Z, Zhou K, Huang Z, Guo X and Zhang Y: LncRNA HOTAIR is a prognostic biomarker for the proliferation and chemoresistance of colorectal cancer via MiR-203a-3p-mediated Wnt/ß-catenin signaling pathway. Cell Physiol Biochem 46: 1275-1285, 2018.

147. Wu KF, Liang WC, Feng L, Pang JX, Waye MM, Zhang JF and Fu WM: H19 mediates methotrexate resistance in colorectal cancer through activating Wnt/ $\beta$-catenin pathway. Exp Cell Res 350: 312-317, 2017.

148. Deng X, Ruan H, Zhang X, Xu X, Zhu Y, Peng H, Zhang X, Kong $\mathrm{F}$ and Guan M: Long noncoding RNA CCAL transferred from fibroblasts by exosomes promotes chemoresistance of colorectal cancer cells. Int J Cancer 146: 1700-1716, 2020.

149. Ma Y, Yang Y, Wang F, Moyer MP, Wei Q, Zhang P, Yang Z, Liu W, Zhang $\mathrm{H}$, Chen $\mathrm{N}$, et al: Long non-coding RNA CCAL regulates colorectal cancer progression by activating Wnt/ $\beta$-catenin signalling pathway via suppression of activator protein $2 \alpha$. Gut 65: 1494-1504, 2016.

150. Hanahan D and Coussens LM: Accessories to the crime: Functions of cells recruited to the tumor microenvironment. Cancer Cell 21: 309-322, 2012.

151. Sun Y: Tumor microenvironment and cancer therapy resistance. Cancer Lett 380: 205-215, 2016.

152. Castellone MD, Teramoto H, Williams BO, Druey KM and Gutkind JS: Prostaglandin E2 promotes colon cancer cell growth through a Gs-axin-beta-catenin signaling axis. Science 310: 1504-1510, 2005.

153. Yang L, Lin C and Liu ZR: P68 RNA helicase mediates PDGF-induced epithelial mesenchymal transition by displacing Axin from beta-catenin. Cell 127: 139-155, 2006.

154. Gupta GP and Massague J: Cancer metastasis: Building a framework. Cell 127: 679-695, 2006.

155. Gross JC, Chaudhary V, Bartscherer K and Boutros M: Active Wnt proteins are secreted on exosomes. Nat Cell Biol 14: 1036-1045, 2012.

156. Hu JL, Wang W, Lan XL, Zeng ZC, Liang YS, Yan YR, Song FY, Wang FF, Zhu XH, Liao WJ, et al: CAFs secreted exosomes promote metastasis and chemotherapy resistance by enhancing cell stemness and epithelial-mesenchymal transition in colorectal cancer. Mol Cancer 18: 91, 2019.

157. Xu X, Chang W, Yuan J, Han X, Tan X, Ding Y, Luo Y, Cai H, Liu Y, Gao X, et al: Periostin expression in intra-tumoral stromal cells is prognostic and predictive for colorectal carcinoma via creating a cancer-supportive niche. Oncotarget 7 : 798-813, 2016

158. Sun Y, Campisi J, Higano C, Beer TM, Porter P, Coleman I, True L and Nelson PS: Treatment-induced damage to the tumor microenvironment promotes prostate cancer therapy resistance through WNT16B. Nat Med 18: 1359-1368, 2012. 
159. Sun Y, Zhu D, Chen F, Qian M, Wei H, Chen W and Xu J: SFRP2 augments WNT16B signaling to promote therapeutic resistance in the damaged tumor microenvironment. Oncogene 35: 4321-4334, 2016.

160. Izumi D, Toden S, Ureta E, Ishimoto T, Baba $H$ and Goel A TIAM1 promotes chemoresistance and tumor invasiveness in colorectal cancer. Cell Death Dis 10: 267, 2019.

161. Takada K, Zhu D, Bird GH, Sukhdeo K, Zhao JJ, Mani M, Lemieux M, Carrasco DE, Ryan J, Horst D, et al: Targeted disruption of the BCL9/ $\beta$-catenin complex inhibits oncogenic Wnt signaling. Sci Transl Med 4: 148ra117, 2012.

162. Tan Z, Huang Q, Zang J, Teng SF, Chen TR, Wei HF, Song DW, Liu TL, Yang XH, Fu CG, et al: HIF-1 $\alpha$ activates hypoxia-induced BCL-9 expression in human colorectal cancer cells. Oncotarget 8: 25885-25896, 2017.

163. Wu X, Gu Z, Chen Y, Chen B, Chen W, Weng L and Liu X: Application of PD-1 blockade in cancer immunotherapy. Comput Struct Biotechnol J 17: 661-674, 2019.

164. Yaghoubi N, Soltani A, Ghazvini K, Hassanian SM and Hashemy SI: PD-1/PD-L1 blockade as a novel treatment for colorectal cancer. Biomed Pharmacother 110: 312-318, 2019.

165. Payandeh Z, Khalili S, Somi MH, Mard-Soltani M, Baghbanzadeh A, Hajiasgharzadeh K, Samadi N and Baradaran B: PD-1/PD-L1-dependent immune response in colorectal cancer. J Cell Physiol 235: 5461-5475, 2020.

166. Topalian SL, Taube JM, Anders RA and Pardoll DM: Mechanism-driven biomarkers to guide immune checkpoint blockade in cancer therapy. Nat Rev Cancer 16: 275-287, 2016.

167. Galon J, Costes A, Sanchez-Cabo F, Kirilovsky A, Mlecnik B, Lagorce-Pages $\mathrm{C}$, Tosolini $\mathrm{M}$, Camus $\mathrm{M}$, Berger $\mathrm{A}$, Wind $\mathrm{P}$, et al: Type, density, and location of immune cells within human colorectal tumors predict clinical outcome. Science 313 1960-1964, 2006

168. Tumeh PC, Harview CL, Yearley JH, Shintaku IP, Taylor EJ, Robert L, Chmielowski B, Spasic M, Henry G, Ciobanu V, et al: PD-1 blockade induces responses by inhibiting adaptive immune resistance. Nature 515: 568-571, 2014.

169. Spranger S, Koblish HK, Horton B, Scherle PA, Newton R and Gajewski TF: Mechanism of tumor rejection with doublets of CTLA-4, PD-1/PD-L1, or IDO blockade involves restored IL-2 production and proliferation of $\mathrm{CD}^{+} \mathrm{T}$ cells directly within the tumor microenvironment. J Immunother Cancer 2: 3, 2014.

170. Spranger S, Dai D, Horton B and Gajewski TF: Tumor-residing Batf3 dendritic cells are required for effector t cell trafficking and adoptive $t$ cell therapy. Cancer Cell 31: 711-723, 2017.

171. Feng M, Jin JQ, Xia L, Xiao T, Mei S, Wang X, Huang X, Chen J, Liu M, Chen C, et al: Pharmacological inhibition of $\beta$-catenin/BCL9 interaction overcomes resistance to immune checkpoint blockades by modulating $\mathrm{T}_{\text {reg }}$. Sci Adv 5: eaau5240, 2019.

172. Bottcher JP and Reis e Sousa C: The role of type 1 conventional dendritic cells in cancer immunity. Trends Cancer 4: 784-792, 2018
173. Liu K, Li J, Wu X, Chen M, Luo F and Li J: GSK-3ß inhibitor 6-bromo-indirubin-3'-oxime promotes both adhesive activity and drug resistance in colorectal cancer cells. Int J Oncol 51 : 1821-1830, 2017.

174. Yan L, Yu HH, Liu YS, Wang YS and Zhao WH: Esculetin enhances the inhibitory effect of 5-Fluorouracil on the proliferation, migration and epithelial-mesenchymal transition of colorectal cancer. Cancer Biomark 24: 231-240, 2019.

175. Cai MH, Xu XG, Yan SL, Sun Z, Ying Y, Wang BK and Tu YX: Regorafenib suppresses colon tumorigenesis and the generation of drug resistant cancer stem-like cells via modulation of miR-34a associated signaling. J Exp Clin Cancer Res 37: 151, 2018.

176. Siraj AK, Kumar Parvathareddy S, Pratheeshkumar P, Padmaja Divya S, Ahmed SO, Melosantos R, Begum R, Concepcion R, Al-Sanea N, Ashari LH, et al: APC truncating mutations in middle eastern population: Tankyrase inhibitor is an effective strategy to sensitize APC mutant CRC To 5-FU chemotherapy. Biomed Pharmacother 121: 109572, 2020

177. Wang J, Min H, Hu B, Xue X and Liu Y: Guanylate-binding protein-2 inhibits colorectal cancer cell growth and increases the sensitivity to paclitaxel of paclitaxel-resistant colorectal cancer cells by interfering Wnt signaling. J Cell Biochem 121: $1250-1259,2020$.

178. Wu CE, Zhuang YW, Zhou JY, Liu SL, Wang RP and Shu P: Cinnamaldehyde enhances apoptotic effect of oxaliplatin and reverses epithelial-mesenchymal transition and stemnness in hypoxic colorectal cancer cells. Exp Cell Res 383: 111500, 2019.

179. Zhao B, Wang L, Qiu H, Zhang M, Sun L, Peng P, Yu Q and Yuan X: Mechanisms of resistance to anti-EGFR therapy in colorectal cancer. Oncotarget 8: 3980-4000, 2017.

180. Sansom OJ, Meniel V, Wilkins JA, Cole AM, Oien KA, Marsh V, Jamieson TJ, Guerra C, Ashton GH, Barbacid M and Clarke AR: Loss of Apc allows phenotypic manifestation of the transforming properties of an endogenous K-ras oncogene in vivo. Proc Natl Acad Sci USA 103: 14122-14127, 2006.

181. He L, Zhu H, Zhou S, Wu T, Wu H, Yang H, Mao H, SekharKathera C, Janardhan A, Edick AM, et al: Wnt pathway is involved in 5-FU drug resistance of colorectal cancer cells. Exp Mol Med 50: 101, 2018

182. Zhao Q, Zhuang K, Han K, Tang H, Wang Y, Si W and Yang Z: Silencing DVL3 defeats MTX resistance and attenuates stemness via Notch signaling pathway in colorectal cancer. Pathol Res Pract 216: 152964, 2020 .

183. Zhang F, Sun H, Zhang S, Yang X, Zhang G and Su T: Overexpression of PER3 inhibits self-renewal capability and chemoresistance of colorectal cancer stem-like cells via inhibition of notch and $\beta$-catenin signaling. Oncol Res 25: 709-719, 2017.

This work is licensed under a Creative Commons Attribution-NonCommercial-NoDerivatives 4.0 International (CC BY-NC-ND 4.0) License. 